\title{
On the mediating role of systemic absorptive capacity: an assessment of FDI effects in developing countries' innovation systems
}

\author{
Bruno Brandão Fischer* \\ Sérgio Queiroz**
}

\begin{abstract}
There is a widespread belief that Foreign Direct Investment (FDI) represents a strategic issue within developing countries' innovation systems. This is a function of expectations that this particular kind of investment can cause positive shocks on host markets' overall capabilities. Our argument, in consonance with dedicated literature, is that these contributions do not take place without "frictions", and that there is a significant complementarity between FDI's effects and the innovation policy framework (particularly those initiatives that influence the existent level of systemic absorptive capacities). Using panel data for developing countries we estimate production functions oriented towards assessing the evolution of National Innovation Systems. Our results suggest that FDI's positive impacts are contingent upon absorptive capacity in developing countries' innovation systems. Nonetheless, its contributions are not pervasive, being robustly related only to labor productivity gains.
\end{abstract}

KEYWORDS | Foreign Direct Investment; National Innovation Systems; Innovation Policy

JEL CODES | F23; O25; O38

\footnotetext{
* Universidade Estadual de Campinas (Unicamp), Campinas (SP), Brasil. E-mail: bruno.fischer@fca.unicamp.br

** Universidade Estadual de Campinas (Unicamp), Campinas (SP), Brasil. E-mail: squeiroz@ige.unicamp.br
} 


\section{O papel mediador das capacidades absortivas sistêmicas: uma abordagem dos efeitos de investimentos estrangeiros diretos em sistemas de inovação de países em desenvolvimento}

\section{RESUMO}

Acredita-se que o investimento estrangeiro direto (IED) represente uma questão estratégica no âmbito dos sistemas de inovação dos países em desenvolvimento. Isso decorre de expectativas de que esse tipo específico de investimento possa causar choques positivos sobre as capacidades dos mercados receptores. $\mathrm{O}$ argumento do presente artigo, em consonância com a literatura dedicada, é que tais contribuições não ocorrem sem "atritos", havendo uma complementaridade significativa entre os efeitos do IED e do quadro da política de inovação (em particular as iniciativas que influenciam o nível existente de capacidades absortivas sistêmicas). A partir de técnicas de dados em painel para países em desenvolvimento, estimamos funções de produção orientadas para avaliar a evolução dos sistemas nacionais de inovação. Os resultados sugerem que os impactos positivos de IED estão subordinados às capacidades absortivas dos sistemas de inovação de países em desenvolvimento. No entanto, suas contribuições são restritas, estando robustamente relacionadas apenas a ganhos de produtividade do trabalho.

PALAVRAS-CHAVE | Investimento Estrangeiro Direto; Sistemas Nacionais de Inovação; Política de Inovação

CÓdigos-JEL | F23; O25; O38 


\section{Introduction}

Foreign Direct Investment attraction consists in a strategic part of the policymaking agenda in developing countries (GUIMÓN, 2009; WARWICK, 2013). The rationale behind such behavior goes beyond pure contributions to domestic stocks of capital. The motivation, instead, is fundamentally supported by endogenous growth models, where knowledge and technology flows are expected to cause positive externalities in host markets (CARKOVIC; LEVINE, 2002), thus benefitting recipient locations with socioeconomic gains. This is a function of potential shifts in the dynamic efficiency of host economies caused by foreign presence, amplifying local aggregate innovative capabilities (BALASUBRAMANYAM et al., 1999).

Nonetheless, there is a lack of agreement on the impacts of FDI flows in host markets. Recently, Narula (2015, p. 19) has stressed that "developing countries have largely liberalised their policies towards FDI, but this is not the same as developing FDI policies. Most take a passive approach to attracting FDI flows, and pay insufficient attention to the nature of the benefits and costs associated with embedding subsidiaries and exploiting externalities". Wooster and Diebel (2010) go even further and argue that empirical literature does not provide reasons to believe that FDI presence in developing economies warrants governmental incentives to the attraction of these firms.

This leads to a debate on whether public expenses on FDI are justifiable, since ex ante estimations of spillovers are highly imperfect (WARWICK, 2013). Consequently, further approaches on the effective interactions between FDI and recipient economies become relevant for innovation policymaking. Aiming at contributing to this context, the focus of this research lies on the concepts of National Innovation Systems (NIS), directing analytical efforts towards MNCs' relationships with innovative performance in host developing markets.

Our investigation is focused on the (expected) mediating role played by innovation capabilities in these processes. As previous assessments have demonstrated (e.g. PEREZ, 1997; GIRMA, 2005), the construction of an adequate economic environment in terms of absorptive capacities within innovation systems is a necessary condition for the appropriation of spillovers by local agents. Hence, the empirical structure of our approach considers R\&D efforts as a proxy for innovation systems' absorptive capacities in host economies, addressing how this dimension relates to the effective contributions arising from the presence of FDI. 
The methodological structure relies on panel data estimations via fixed-effects models for 31 developing countries over the period 1993-2008. In order to build a comprehensible picture of innovation systems, five dependent constructs were appraised: (i) labor productivity, (ii) growth rate in Total Factor Productivity (TFP), (iii) USPTO patenting activity, (iv) export intensity in high-technology products, and (v) registration of trademarks. Models are developed according to augmented versions of production functions.

The article is structured as follows: section 2 addresses issues related to impacts of FDI on host markets. Section 3 reviews the literature regarding the conditionality of FDI's externalities upon aggregate levels of absorptive capacity. A research hypotheses is derived from theoretical remarks. The methodological structure is presented in section 4. Results are discussed in section 5, and section 6 concludes with implications for the analysis and promotion of FDI from a NIS perspective.

\section{FDI and national innovation systems}

Foreign Direct Investments constitute a particular sort of international capital flows that is strictly related to productive activities, usually carried out by multinational corporations. There is a widespread perception that these investments play a central role within host markets' innovation systems (GUIMÓN, 2009), integrating technological capabilities across countries and generating beneficial socioeconomic returns (besides the internalization of private gains). The rationale behind this proposition is that MNCs possess above-average assets (tangible and intangible), constituting "hubs" of skills, technology and managerial expertise (NOORBAKHSH; PALONI, 2001).

Nonetheless, private advantages do not justify the inclusion of FDI attraction in innovation and industrial policy frameworks. If overall capabilities could be perfectly internalized, MNCs would contribute to recipient economies only through evolutionary process of resource reallocation caused by competitive pressure (ALFARO et al., 2004; KOKKO, 1994). Although aggregate productivity can be enhanced in this situation, negative shocks in groups of indigenous firms can offset the gains from a systemic point of view. However, perfect internalization of assets is unlikely to exist. Instead, there is an expectation that positive externalities (knowledge/technology spillovers) will take place. In this regard, benefits arising 
from multinationals are related to learning processes, generation of networks, and training of the labor force (ALFARO et al., 2004), providing host markets with increasing returns and other beneficial shocks in productivity (DE MELLO, 1997; WARWICK, 2013).

Under the traditional neoclassical perspective, these productive investment inflows represent engines of economic convergence between nations as a function of diminishing marginal productivity of capital, i.e., having higher economic impacts in less developed and developing countries (DE MELLO, 1997). The argument is that countries occupying laggard technological positions depend on the diffusion of knowledge generated in more advanced locations in order to evolve economically (BALASUBRAMANYAM et al., 1999). In its turn, FDI provides these nations with the means to access state-of-the-art technologies, productive know-how and managerial practices (BORENSZTEIN et al., 1998; BALASUBRAMANYAM et al., 1996; DE MELLO, 1997).

On the other hand, as Blomstrom et al. (1996), and Xu (2000) have demonstrated, FDI's impacts actually seem to be stronger in more advanced economies. In a similar vein, Wooster and Diebel (2010), through a meta-analytical exercise, pinpoint that countries in more advanced stages of development are more capable of accruing benefits from FDI as a function of their respective aggregate technological positions. These empirical findings are representations of endogenous growth approaches' validity concerning the role of FDI within innovative dynamics. In this case, the theoretical rationale that supports the perspective of systemic contributions of FDI regarding host economies is based on economic models that take the generation of knowledge and technology as self-reinforcing features. These approaches allow foreign investments to continually exert influences on the technological environment by creating and diffusing innovations (NAIR-REICHERT; WEINHOLD, 2001). The main links connecting the activity of MNCs to this theoretical perspective are related to the generation of externalities, R\&D investments and learning-by-doing processes (DE MELLO, 1997), i.e., systemic shocks that spread their influence across countries' economic structures.

The inclusion of FDI in production functions comes with a remarkable implication: active policymaking becomes a fundamental dimension of influence in these dynamics. Consequently, the expected beneficial impacts of inward FDI justify the incorporation of this item in the innovation policy agenda (WARWICK, 2013). More emphasis on institutional settings is supplied by Nair-Reichert and 
Weinhold (2001): they found that positive contributions from FDI are conditional upon host markets' characteristics and their capacity of establishing effective connections with foreign subsidiaries. Therefore, the existence of "frictions" in the process of spillovers' generation brings forward a lack of agreement on whether social or private returns prevail in the dynamics of FDI (BALASUBRAMANYAM et al., 1999). The innovation system framework, designed and affected by dedicated policies, functions as a catalyst in this context, i.e., it drives the aggregate capability of nations to promote the desired flows of productive knowledge. This topic is further discussed in the next section.

\section{On the conditionality of FDI spillovers: the role of absorptive capacity}

As outlined in the previous section, there is an expectation that inward FDI has the capacity of exerting positive influences in host countries' economic environments. This situation, however, does not take place without "frictions" that hinder the mobility of firms' intangible assets. Literature has suggested that FDI's beneficial impacts are conditional upon institutional settings of the host market, as well as on the governmental capacity to manage these dimensions (CARKOVIC; LEVINE, 2002; BALASUBRAMANYAM et al., 1999; DE MELLO, 1997; FRANSMAN, 1995; KOKKO, 1994; DUNNING, 1994). It is not a novel argument to pinpoint the criticality of these elements in developing countries' innovation systems. On the other hand, though FDI attraction policies have become a trend, initiatives often fail to address issues related to the very nature of benefits arising from the presence of MNCs (NARULA; DUNNING, 2010).

This lack of coordination between specific and systemic policies may yield undesirable outcomes. Wooster and Diebel (2010), call attention to the significance of FDI spillovers in developing countries exhibiting at best weak positive externalities. Moreover, in the absence of fundamental conditions, foreign direct investments can be counterproductive, diluting the possibility of increased social returns in the host market (BALASUBRAMANYAM et al., 1996; DE MELLO, 1997), and having perverse impacts on recipient economies (MAYER-FOULKES; NUNNENKAMP, 2009; DUNNING, 1994).

In this regard, the presence of foreign capital in developing countries can be associated to lower innovative efforts in local industries. This happens because MNCs 
often centralize their R\&D activities in their home markets, thus reducing overall levels of innovation-related investments abroad (LALL, 1992; ZUCOLOTO; TONETO JR., 2005; FURTADO; CARVALHO, 2005). ${ }^{1}$ Aitken and Harrison (1999) find that the presence of foreign capital negatively affects productivity in indigenous competitors. Girma (2005) reports negative impacts on total factor productivity arising from the allocation of FDI in regions that lack minimum levels of absorptive capacity. In this case, a "displacement effect" drives local companies out of business (BORENSZTEIN et al., 1998), potentially affecting the productive structure of host markets in the long run. Dunning (1994) concludes that these allocation dynamics (in markets that lack sufficient capabilities) may lead to a situation in which locallevel innovative capacity decreases. Perez (1997) identifies that, in markets where local technological capabilities are weak, the presence of MNCs is bound to reduce indigenous agents' profitability and R\&D activity, leading to a cumulative process of technological decline (also see LALL, 1992).

To mediate this situation, attention must be given to systemic absorptive capacities (GIRMA, 2005), and the facilitating role of industrial and innovation policies. According to the seminal foundations of the absorptive capacity concept, technological learning and diffusion require the existence of prior related knowledge (COHEN; LEVINTHAL, 1990). Though originally oriented towards the microeconomic environment, this conceptual landmark has been adapted to aggregate analyses concerning innovation systems (e.g. LALL, 1992; KINOSHITA, 2000). The underlying principle is straightforward: FDI's intangible assets spill over firms' boundaries, but their effective contribution to innovation systems is contingent upon existing learning abilities of indigenous agents.

The analytical dimensions which represent the idea of absorptive capacity are vast. For our research interests, the focus lies in identifying a proxy for innovation systems' level of development, allowing the assessment of their respective absorptive capacities concerning advanced technologies and industrial know-how (LALL, 1992). In this regard, aggregate innovative efforts address the technological position and the level of accumulated knowledge that is locally available in a given NIS. Countries that lag behind in innovation input indicators often demonstrate meager capabilities in comparison to more advanced nations. Kinoshita (2000) is a leading example of an attempt to interact FDI and R\&D efforts in search for conditional spillovers. His findings support the role of $R \& D$ investment as an important determinant

1 We would like to thank an anonymous reviewer for this discussion. 
of absorptive capacity regarding FDI externalities. Accordingly, Castellacci and Natera (2013) have found that aggregate R\&D expenditures positively influence the conditions of absorptive capacity of macroeconomic systems and their respective level of innovation evolution, thus offering support for the use of this construct as a robust proxy for NIS's capabilities.

The discussion developed in the theoretical framework exposed in sections 2 and 3 drive us to the fundamental questions of this research: does FDI represent an important vector for the evolution of developing countries' innovation systems? What is the relevance of system-level absorptive capacities (in terms of R\&D efforts) in this process? We translate these inquiries into the following research hypothesis that will guide our empirical exercise:

$H_{1}$ : The existence of FDI's positive impacts on the functioning and outcomes of developing countries' innovation systems is contingent upon existing aggregate levels of absorptive capacity as approximated by $R \& D$ expenditures.

In the next section we describe the methodological structure of our empirical assessment which aims at further investigating the issues raised in the previous sections and summarized in our research hypothesis $\left(\mathrm{H}_{1}\right)$.

\section{Methodological structure}

The empirical approach comprehends data for 31 developing countries (see Appendix I for the list of countries) ${ }^{2}$ throughout the period 1993-2008 (unbalanced panel). This particular timeframe allows satisfactory conditions in terms of missing data, and it also avoids undesirable fluctuations derived from the 2008 financial crisis. This latter item is relevant for our research interests, since global financial markets' shocks can distort the prevalence of fundamental forces of economic activity and the natural behavior of agents, thus potentially distorting theoretical and policy implications of our analytical exercise. Before discussing the econometric models, we present the variables included in the empirical analysis (Table 1).

2 Developing countries (or DCs) are part of the group of nations classified as "upper-middle income" as of June, 2014. See <http:// data.worldbank.org/about/country-and-lending-groups> for details. 
Table 1

Analytical variables ${ }^{3}$

\begin{tabular}{|c|c|c|}
\hline Code & Definition & Source \\
\hline PROD & $\begin{array}{l}\text { Labor productivity per person employed in } 2014 \text { US\$ } \\
\text { (converted to } 2014 \text { price level with updated } 2011 \\
\text { PPPs). }\end{array}$ & Conference Board \\
\hline TFPGRT & $\begin{array}{l}\text { Growth of Total Factor Productivity (estimated as a } \\
\text { Tornqvist Index). }\end{array}$ & Conference Board \\
\hline PATS & $\begin{array}{l}\text { Number of utility patents granted by the USPTO } \\
\text { by year and Inventor's Country of Residence per } \\
\text { inhabitant. }\end{array}$ & CANA Dataset \\
\hline HITECHX & $\begin{array}{l}\text { Export intensity in high-tech products (\% of } \\
\text { total exports), such as aerospace, computers, } \\
\text { pharmaceuticals, scientific instruments and electrical } \\
\text { machinery. }\end{array}$ & World Bank \\
\hline TRDMRK & Total number of trademark applications. & World Bank \\
\hline FDI & Inward Foreign Direct Investment Stocks (\% of GDP). & UNCTAD \\
\hline K & $\begin{array}{l}\text { Total investment as represented by gross fixed capital } \\
\text { formation ( } \% \text { of GDP). }\end{array}$ & World Bank \\
\hline GDPPC & GDP per capita (constant 2005 USD). & World Bank \\
\hline GINI & Gini index. & CANA Dataset \\
\hline OPEN & $\begin{array}{l}\text { Openness to trade measured as the sum of exports and } \\
\text { imports ( } \% \text { of GDP). }\end{array}$ & World Bank \\
\hline $\mathrm{L}$ & $\begin{array}{l}\text { Total labor force (aged } 15 \text { and older, employed and } \\
\text { unemployed). }\end{array}$ & World Bank \\
\hline INF & $\begin{array}{l}\text { Inflation as measured by the consumer price index } \\
(\%) \text {. }\end{array}$ & World Bank \\
\hline $\mathrm{ABC} 1$ & Gross expenditures in R\&D (\% of GDP). & CANA Dataset \\
\hline $\mathrm{ABC} 2$ & $\begin{array}{l}\text { Absorptive capacity dummy. Values above the median } \\
\text { in } A B C 1 \text { take the value of " } 1 \text { ", " } 0 \text { " otherwise. }\end{array}$ & CANA Dataset \\
\hline
\end{tabular}

Source: The authors.

\subsection{Empirical models}

The fundamental augmented production function that is applied in empirical approaches dedicated to address economic growth impacts of FDI upon host economies takes the following structure (DE MELLO, 1997): 
$Y=A(K, L, F D I, \Omega)$

Equation 1. Fundamental analytical structure

As in the standard neoclassical form (MANKIW ET AL., 1992), $Y$ denotes economic output, $A$ stands for Total Factor Productivity (TFP), $K$ is capital and $L$ is labor. The extension of this basic model includes FDI (inward foreign direct investment), and $\Omega$ as a flexible set of ancillary variables (for the full definition of variables see Table 1 ).

In each operational model of our analysis, $Y$ stands for output indicators (PROD, TFPGRT, PATS, HITECHX, and TRDMRK). This is a derivation we have made regarding Equation 1 concerning the dependent elements of regressions. Whereas usual estimations take economic output $(\mathrm{Y})$ as an element of aggregate production (growth dynamics in GDP), we aim at assessing more specific indicators of innovative capacity within National Innovation Systems. This procedure allows a more direct evaluation of potential impacts of FDI's spillovers, since relationships between positive externalities and aggregate economic output are expected to happen via shocks in intermediary activities. Consequently, we believe traditional estimations found in literature may contain a significant amount of noise in statistical relationships.

It should be noticed that our dependent variables are measured in a way to effectively capture their roles in the context of developing countries' innovation systems (instead of resorting solely to the standard economic growth approach). While TFP is measured in its respective rate of growth, the remaining dependent vectors are assessed in levels (or GDP share in the case of HITECHX). This allows avoiding statistical issues related to stochastic patterns in the growth rates of these variables (not present in GDP per capita growth, for instance), which may render production functions inefficient. In this regard, we follow similar applications of models reported elsewhere (BLALOCK; SIMON, 2009; FU, 2008; BLOMSTROM; PERSSON, 1983). Furthermore, as models apply natural logs to both terms of regressions, our interest will lie in the evaluation of dependent variables' elasticities respect to predictors, thus offering a consistent perspective on the evolutionary dynamics of innovation systems in laggard economies. We depart from this proposition to set the functional form of our first analytical model (model I):

$\operatorname{Ln} Y_{i t}=\alpha+\beta_{1} \operatorname{Ln} K_{i t}+\beta_{2} L n L_{i t}+\beta_{3} L n F D I_{i t}+\beta 4 \Omega 1_{i t}+\mu_{i}+\varepsilon_{i t}$

Equation 2. Model I 
Where $K$ offers a control for the situation of overall domestic investment, a potential source of gains in the three dependent dimensions that are addressed in our study, and it is a proxy for capital. $L$ contains information regarding total labor pools (also offering a control for country size). $\Omega 1$ represents the natural logs of OPEN and INF. OPEN is a proxy for trade policy regimes, which affect the competitive environments. It also influences the efficiency of FDI as a generator of social returns (BALASUBRAMANYAM et al., 1999; DE MELLO, 1997), and it has demonstrated a potential to increase innovative capabilities through knowledge spillovers (COE; HELPMAN, 1995; POTTELSBERGHE; LICHTENBERG, 2001). INF functions as a control for economic stability of nations, a potential source of shocks (positive or negative) upon output indicators, and variations in values of GDP per capita. ${ }^{4} \alpha$ is the constant, $\beta_{k}$ is the $\mathrm{k}^{\text {th }}$ coefficient of predictors, $i$ is the identifier of each cross-section unit, $t$ is identifier of each time-period, $\mu_{i}$ is the time-invariant error term, and $\varepsilon_{i t}$ is the observation-specific error term.

However, we aim at adapting these guidelines to a view of R\&D efforts as a mediating vector economic systems' evolution. In order to evaluate the expected intermediary role played by this source of absorptive capacity used in our analysis $(\mathrm{R} \& D)$, we have created interaction terms (FDI*ABC1 and $\mathrm{FDI}^{*} \mathrm{ABC} 2$, see table 1 for the definition of analytical variables). This allows the verification of associations between "pure" and "conditional" impacts of FDI within host economic systems. In this regard we follow the analytical structure proposed by Kinoshita (2000) and $\mathrm{Fu}$ (2008). Furthermore, we have addressed absorptive capacity in two manners (for robustness purposes). $\mathrm{ABC} 1$ represents continuous observations of $\mathrm{R} \& \mathrm{D}$ intensity. $\mathrm{ABC} 2$ is a dummy transformation of GERD as proposed by Carkovic and Levine (2002). Values related to absorptive capacity in ABC2 then take the value 1 whenever it is equal or it exceeds the median in $\mathrm{ABC} 1 .^{5}$ The inclusion of $\mathrm{ABC} 1$ is not performed in other models because the simultaneous inclusion of interactive terms and both of its components generated collinearity issues that hindered the application of models during estimations (an issue that has been already pointed out by Carkovic and Levine, 2002). This leads us to models II and III:

\footnotetext{
4 Although this variable is measured in current USD, the inclusion of INF in the estimations provides a control for fluctuations in values over time.

5 Although these levels are arbitrarily defined, they represent instructive ways of exploring results from absorptive capacity assessments.
} 
$\operatorname{Ln} Y_{i t}=\alpha+\beta_{1} L n K_{i t}+\beta_{2} L n L_{i t}+\beta_{3} L n F D I_{i t}+\beta_{4} L n F D I^{*} A B C 1_{i t}+\beta_{5} \Omega 1_{i t}+\mu_{i}+\varepsilon_{i t}$

Equation 3. Model II

$L n Y_{i t}=\alpha+\beta_{1} L n K_{i t}+\beta_{2} L n L_{i t}+\beta_{3} L n F D I_{i t}+\beta_{4} L n F D I^{*} A B C 2_{i t}+\beta_{5} A B C 2_{i t}+\beta_{6} \Omega 1_{i t}+\mu_{i}+\varepsilon_{i t}$

Equation 4. Model III

In order to develop further robustness tests, two additional models are created with the inclusion of an additional set of ancillary variables $(\Omega 2)$ represented by GINI (Gini Index) and GDPPC (GDP per capita). The use of GDPPC functions as a control for the level of income of countries included in the sample. GDP per capita also controls for the purchasing power of the domestic market, a factor that is likely to drive output growth both quantitatively and qualitatively (BALASUBRAMANYAM et al., 1999). Despite the importance of GDPPC as a control for output variables (BALASUBRAMANYAM et al., 1999), there is an inherent risk of endogeneity between this variable and dependent constructs. This feature explains the absence of GDPPC in models I, II and III. ABC2 is included separately in models III and $\mathrm{V}$ to control for the direct effects of this variable upon output indicators and to have a better grasp on the individual relevance of the $R \& D$ dimension. The Gini coefficient functions as a control for income distribution (which can be also associated with institutional quality ${ }^{6}$. Models IV and $\mathrm{V}$ take the following functional form:

$$
\operatorname{Ln} Y_{i t}=\alpha+\beta_{1} \operatorname{Ln} K_{i t}+\beta_{2} L n L_{i t}+\beta_{3} L n F D I_{i t}+\beta_{4} L n F D I^{*} A B C 1_{i t}+\beta_{5} \Omega 1_{i t}+\beta_{6} \Omega 2_{i t}+\mu_{i}+\varepsilon_{i t}
$$

Equation 5. Model IV

$$
L n Y_{i t}=\alpha+\beta_{1} L n K_{i t}+\beta_{2} L n L_{i t}+\beta_{3} L n F D I_{i t}+\beta_{4} L n F D I^{*} A B C 2_{i t}+\beta_{5} A B C 2_{i t}+\beta_{6} \Omega 1_{i t}+\beta_{7} \Omega 2_{i t}+\mu_{i}+\varepsilon_{i t}
$$

Equation 6. Model V

The estimation method is that of fixed-effects for panel data. The use of this particular strategy represents a fundamental tool in the verification of FDI effects upon economic systems' dynamics, since it allows consistent estimates of time-constant omitted variables upon dependent constructs (WOOLDRIDGE, 2000), a desirable feature in the assessment of innovation systems' evolution. 


\section{Results}

Table 2 brings a descriptive summary of the main independent variables of interest in this research. The variable FDI (\% of GDP) shows a strong variation in a comparison between minimum and maximum values, but only a moderate coefficient of variation. ${ }^{7}$ In terms of $\mathrm{ABC} 1$, i.e., $\mathrm{R} \& \mathrm{D}$ intensity, the behavior of the sample is more homogeneous than for FDI, although significant differences are in place ${ }^{8}$ between developing countries.

Table 2

Descriptive summary of FDI and ABC1

\begin{tabular}{c|c|c|c|c|c}
\hline & Mean & Median & Minimum & Maximum & $\begin{array}{c}\text { Coefficient of } \\
\text { Variation (\%) }\end{array}$ \\
\hline $\begin{array}{c}\text { FDI } \\
\text { \% of GDP) }\end{array}$ & 27.06 & 22.04 & $\begin{array}{c}0.04 \\
\text { Russia, 1993 }\end{array}$ & $\begin{array}{c}128.48 \\
\text { Lebanon, 2007 }\end{array}$ & 80.55 \\
$\begin{array}{c}\text { ABC1 } \\
(\% \text { of GDP })\end{array}$ & 0.47 & 0.43 & $\begin{array}{c}0.03 \\
\text { Ecuador, } \\
1993\end{array}$ & $\begin{array}{c}1.48 \\
\text { China, } 2007\end{array}$ & 57.5 \\
\hline
\end{tabular}

Source: The authors (based on data analysis for the sample).

Results from fixed-effects estimations for each model specification are presented in Tables 3 (Productivity as dependent dimension), 4 (TFP growth), 5 (USPTO patents), 6 (High-tech exports), and 7 (Trademarks).

We refrain from thorough examinations of outcomes associated to models' controls in favor of a deeper understanding of the core vectors under scrutiny, i.e., FDI, FDI*ABC1 and $\mathrm{FDI}^{*} \mathrm{ABC} 2$. It is enough to state that controls largely follow theoretical expectations, whereas special emphasis can be put on the strong role played by NISs' openness to trade in relation to positive dynamics of systems' functioning and outcomes.

7 For example, high income countries present a CV of $104.27 \%$ in this indicator, although levels of FDI are consistently higher in this group of nations (minimum $0.34 \%$, maximum $238.75 \%$ ).

8 Levels of heterogeneity for R\&D investments are actually similar to those found in high-income countries $(\mathrm{CV}=58.16 \%$, minimum $=0.04 \%$, maximum $=4.86 \%)$. 
Table 3

Estimations for LnPROD (dependent)

\begin{tabular}{|c|c|c|c|c|c|}
\hline Variables & Model I & Model II & Model III & Model IV & Model V \\
\hline const. & $\begin{array}{c}11.485^{* * *} \\
{[1.256]}\end{array}$ & $\begin{array}{c}11.870^{* * *} \\
{[1.282]}\end{array}$ & $\begin{array}{c}10.713^{* * *} \\
{[1.227]}\end{array}$ & $\begin{array}{c}13.681^{* * *} \\
{[.893]}\end{array}$ & $\begin{array}{c}12.566^{* * *} \\
{[.928]}\end{array}$ \\
\hline LnK & $\begin{array}{l}.116^{* * *} \\
{[.024]}\end{array}$ & $\begin{array}{l}.108^{* * *} \\
{[.023]}\end{array}$ & $\begin{array}{l}.096^{* * *} \\
{[.022]}\end{array}$ & $\begin{array}{c}-.047^{* * *} \\
{[.016]}\end{array}$ & $\begin{array}{c}-.055^{* * *} \\
{[.016]}\end{array}$ \\
\hline $\mathrm{LnL}$ & $\begin{array}{l}-.075 \\
{[.078]}\end{array}$ & $\begin{array}{l}-.063 \\
{[.077]}\end{array}$ & $\begin{array}{l}-.038 \\
{[.075]}\end{array}$ & $\begin{array}{c}-.324^{* * *} \\
{[.054]}\end{array}$ & $\begin{array}{c}-.296^{* * *} \\
{[.057]}\end{array}$ \\
\hline LnFDI & $\begin{array}{l}.028^{* *} \\
{[.013]}\end{array}$ & $\begin{array}{c}-.063^{* *} \\
{[.024]}\end{array}$ & $\begin{array}{l}-.033^{*} \\
{[.019]}\end{array}$ & $\begin{array}{c}-.100^{* * *} \\
{[.018]}\end{array}$ & $\begin{array}{c}-.053^{* * *} \\
{[.015]}\end{array}$ \\
\hline LnOPEN & $\begin{array}{l}.354^{* * *} \\
{[.052]}\end{array}$ & $\begin{array}{l}.223^{* * *} \\
{[.055]}\end{array}$ & $\begin{array}{l}.312^{* * *} \\
{[.051]}\end{array}$ & $\begin{array}{l}.158^{* * *} \\
{[.036]}\end{array}$ & $\begin{array}{l}.249^{* * *} \\
{[.035]}\end{array}$ \\
\hline LnINFLATION & $\begin{array}{c}-.032^{* * *} \\
{[.007]}\end{array}$ & $\begin{array}{c}-.023^{* * *} \\
{[.007]}\end{array}$ & $\begin{array}{c}-.030^{* * *} \\
{[.007]}\end{array}$ & $\begin{array}{l}-.008 \\
{[.005]}\end{array}$ & $\begin{array}{c}-.014^{* * *} \\
{[.005]}\end{array}$ \\
\hline LnFDI*ABC1 & - & $\begin{array}{c}.103^{* * *} \\
{[.023]}\end{array}$ & - & $\begin{array}{c}.101^{* * *} \\
{[.017]}\end{array}$ & - \\
\hline LnFDI*ABC2 & - & - & $\begin{array}{l}.080^{* * *} \\
{[.018]}\end{array}$ & - & $\begin{array}{l}.055^{* * *} \\
{[.014]}\end{array}$ \\
\hline $\mathrm{ABC} 2$ & - & - & $\begin{array}{l}.634^{* * *} \\
{[.122]}\end{array}$ & - & $\begin{array}{l}.405^{* * *} \\
{[.102]}\end{array}$ \\
\hline LnGINI & - & - & - & $\begin{array}{l}.189^{* * *} \\
{[.054]}\end{array}$ & $\begin{array}{l}.151^{* * *} \\
{[.056]}\end{array}$ \\
\hline LnGDPPC & - & - & - & $\begin{array}{l}.292^{* * *} \\
{[.013]}\end{array}$ & $\begin{array}{l}.288^{* * *} \\
{[.014]}\end{array}$ \\
\hline $\mathrm{R}^{2}$ & .900 & .908 & .913 & .972 & .970 \\
\hline Valid N & 362 & 346 & 346 & 271 & 271 \\
\hline $\begin{array}{l}\text { Std. Errors in } \\
\text { brackets }\end{array}$ & \multicolumn{5}{|c|}{$\begin{array}{l}{ }^{*} \text { sig. at } 10 \% ;{ }^{* *} \text { sig. at } 5 \% ; \\
{ }^{* * *} \text { sig. at } 1 \%\end{array}$} \\
\hline
\end{tabular}

Source: The authors (based on data analysis for the sample).

In all evaluations, once we accounted for the possibility of conditional spillovers through the introduction of interaction terms, the "pure" effects of FDI, i.e., FDI effects at very low levels of R\&D investments, became either negative or statistically non-significant. This is much in line with the findings of Aitken and Harrison (1999) for productivity, Girma (2005) for TFP, and Dunning (1994), Perez (1997) and Lall (1992) for aggregate innovative capacity. This is never the case for the estimations of Model I where the association of FDI to dependent variables is consistently positive and significant (except for TFP growth). This contrast highlights the practical importance (and its policy-level implications) related to econometric specifications 
for the assessment of FDI-related impacts which can provide unrealistic expectations on the potential benefits of attracting MNCs to the environment of developing countries (see Wooster and Diebel, 2010).

In model II, where $\mathrm{ABC} 1$ is used as the proxy for aggregate absorptive capacity, we can see that FDI's impacts show a positive trend for countries with higher levels of R\&D efforts. This can be noticed through the comparative evaluation of coefficients in LnFDI*ABC1 (positive and significant) and LnFDI (negative and significant). Furthermore, the magnitude of these coefficients suggests the importance of R\&D investments in capturing beneficial impacts from FDI. Net effects seem to be particularly large in patenting activity, registration of Trademarks (in both cases LnFDI is not significantly different from zero), and TFP growth. Gains in labor productivity are rather marginal in a comparison with the abovementioned dimensions.

Table 4

Estimations for LnTFP (dependent)

\begin{tabular}{|c|c|c|c|c|c|}
\hline Variables & Model I & Model II & Model III & Model IV & Model V \\
\hline const. & $\begin{array}{c}4.675 \\
{[12.023]}\end{array}$ & $\begin{array}{c}29.176 * * \\
{[13.855]}\end{array}$ & $\begin{array}{c}16.611 \\
{[13.255]}\end{array}$ & $\begin{array}{l}30.340^{*} \\
{[16.826]}\end{array}$ & $\begin{array}{c}20.961 \\
{[16.762]}\end{array}$ \\
\hline LnK & $\begin{array}{l}-.226 \\
{[.344]}\end{array}$ & $\begin{array}{c}.143 \\
{[.366]}\end{array}$ & $\begin{array}{c}.056 \\
{[.372]}\end{array}$ & $\begin{array}{c}.247 \\
{[.488]}\end{array}$ & $\begin{array}{c}.081 \\
{[.492]}\end{array}$ \\
\hline $\mathrm{LnL}$ & $\begin{array}{c}-.510 \\
{[.746]}\end{array}$ & $\begin{array}{c}-1.805^{* *} \\
{[.822]}\end{array}$ & $\begin{array}{l}-1.224 \\
{[.816]}\end{array}$ & $\begin{array}{l}-1.703 * \\
{[1.017]}\end{array}$ & $\begin{array}{l}-1.423 \\
{[1.037]}\end{array}$ \\
\hline LnFDI & $\begin{array}{c}.115 \\
{[.143]}\end{array}$ & $\begin{array}{l}-.422 * \\
{[.244]}\end{array}$ & $\begin{array}{c}.007 \\
{[.203]}\end{array}$ & $\begin{array}{l}-.558^{*} \\
{[.283]}\end{array}$ & $\begin{array}{c}-.200 \\
{[.254]}\end{array}$ \\
\hline LnOPEN & $\begin{array}{l}.333 \\
{[.510]}\end{array}$ & $\begin{array}{c}.590 \\
{[.585]}\end{array}$ & $\begin{array}{c}.942 \\
{[.578]}\end{array}$ & $\begin{array}{c}.496 \\
{[.673]}\end{array}$ & $\begin{array}{l}1.103^{*} \\
{[.661]}\end{array}$ \\
\hline LnINFLATION & $\begin{array}{l}.117 * \\
{[.060]}\end{array}$ & $\begin{array}{c}.092 \\
{[.068]}\end{array}$ & $\begin{array}{c}.070 \\
{[.070]}\end{array}$ & $\begin{array}{c}.077 \\
{[.078]}\end{array}$ & $\begin{array}{c}.031 \\
{[.083]}\end{array}$ \\
\hline LnFDI*ABC1 & - & $\begin{array}{l}.527 * * \\
{[.221]}\end{array}$ & - & $\begin{array}{l}.664 * * \\
{[.259]}\end{array}$ & - \\
\hline LnFDI*ABC2 & - & - & $\begin{array}{c}.039 \\
{[.183]}\end{array}$ & - & $\begin{array}{c}.303 \\
{[.246]}\end{array}$ \\
\hline $\mathrm{ABC} 2$ & - & - & $\begin{array}{c}.308 \\
{[1.235]}\end{array}$ & - & $\begin{array}{c}2.213 \\
{[1.717]}\end{array}$ \\
\hline LnGINI & - & - & - & $\begin{array}{c}-.024 \\
{[.817]}\end{array}$ & $\begin{array}{l}-.409 \\
{[.859]}\end{array}$ \\
\hline LnGDPPC & - & - & - & $\begin{array}{l}-.186 \\
{[.228]}\end{array}$ & $\begin{array}{l}-.177 \\
{[.244]}\end{array}$ \\
\hline $\mathrm{R}^{2}$ & .334 & .366 & .347 & .320 & .297 \\
\hline Valid N & 224 & 211 & 211 & 166 & 166 \\
\hline $\begin{array}{l}\text { Std. Errors in } \\
\text { brackets }\end{array}$ & & & $\begin{array}{l}* \text { sig. at } 10 \% ; \\
* * \text { sig. at } 5 \% ; \\
* * * \text { sig. at } 1 \%\end{array}$ & & \\
\hline
\end{tabular}

Source: The authors (based on data analysis for the sample). 
This behavior, however, does not hold for the assessment of export intensity in high-tech products (table 6), in which case effects from FDI are non-significant in the presence of mediating repercussions associated to $\mathrm{ABC} 1$. Curiously, results for this NIS indicator are also the only ones not to identify negative influences for FDI in estimations II and IV (or in any other regression). We believe this can be related to weak participation of high-tech products in the exports of developing countries in general (for our sample, mean $=8.9 \%$, median $=4.5 \%$, std.dev. $=12 \%$ ). Also, while some of these activities have been transferred to developing markets (such as China, Brazil and Mexico), the bulk of high-tech, R\&D-intensive, exports is concentrated in developed nations. This is strongly related to firms' productive strategies, the necessity of knowledge inputs and the relatively low price-elasticity of high-tech markets. These aspects can explain the results for the HITECHX dimension (which are robust throughout models II to V).

Table 5

Estimations for LnPATS (dependent)

\begin{tabular}{|c|c|c|c|c|c|}
\hline Variables & Model I & Model II & Model III & Model IV & Model V \\
\hline const. & $\begin{array}{c}-18.157 * * * \\
{[5.470]}\end{array}$ & $\begin{array}{c}-11.995 * * \\
{[5.726]}\end{array}$ & $\begin{array}{c}-16.766 * * * \\
{[5.581]}\end{array}$ & $\begin{array}{l}-2.751 \\
{[7.345]}\end{array}$ & $\begin{array}{c}-8.763 \\
{[7.509]}\end{array}$ \\
\hline LnK & $\begin{array}{l}-.085 \\
{[.107]}\end{array}$ & $\begin{array}{l}-.067 \\
{[.105]}\end{array}$ & $\begin{array}{c}-.095 \\
{[.106]}\end{array}$ & $\begin{array}{c}-.274 * * * \\
{[.119]}\end{array}$ & $\begin{array}{c}-.322 * * * \\
{[.122]}\end{array}$ \\
\hline $\mathrm{LnL}$ & $\begin{array}{c}.229 \\
{[.339]}\end{array}$ & $\begin{array}{l}-.021 \\
{[.343]}\end{array}$ & $\begin{array}{c}.125 \\
{[.345]}\end{array}$ & $\begin{array}{c}-.725 \\
{[.439]}\end{array}$ & $\begin{array}{l}-.603 \\
{[.459]}\end{array}$ \\
\hline LnFDI & $\begin{array}{l}.114 \% \\
{[.059]}\end{array}$ & $\begin{array}{l}-.234 \\
{[.123]}\end{array}$ & $\begin{array}{c}.046 \\
{[.095]}\end{array}$ & $\begin{array}{c}-.566 * * * \\
{[.154]}\end{array}$ & $\begin{array}{l}-.015 \\
{[.119]}\end{array}$ \\
\hline LnOPEN & $\begin{array}{c}.901 * * * \\
{[.237]}\end{array}$ & $\begin{array}{c}.588 \\
{[.253]}\end{array}$ & $\begin{array}{c}.890 * * * \\
{[.236]}\end{array}$ & $\begin{array}{c}.327 \\
{[.285]}\end{array}$ & $\begin{array}{l}.849 * * * \\
{[.271]}\end{array}$ \\
\hline LnINFLATION & $\begin{array}{l}-.064 * \\
{[.036]}\end{array}$ & $\begin{array}{l}-.049 \\
{[.035]}\end{array}$ & $\begin{array}{l}-.069 * \\
{[.035]}\end{array}$ & $\begin{array}{l}-.042 \\
{[.040]}\end{array}$ & $\begin{array}{c}-.065 \\
{[.041]}\end{array}$ \\
\hline LnFDI*ABC1 & - & $\begin{array}{l}.385 * * * \\
{[.120]}\end{array}$ & - & $\begin{array}{c}.648 * * * \\
{[.153]}\end{array}$ & - \\
\hline LnFDI*ABC2 & - & - & $\begin{array}{c}.088 \\
{[.092]}\end{array}$ & - & $\begin{array}{c}.064 \\
{[.112]}\end{array}$ \\
\hline $\mathrm{ABC} 2$ & - & - & $\begin{array}{c}.866 \\
{[.631]}\end{array}$ & - & $\begin{array}{c}.688 \\
{[.780]}\end{array}$ \\
\hline LnGINI & - & - & - & $\begin{array}{l}.685^{*} \\
{[.400]}\end{array}$ & $\begin{array}{c}.535 \\
{[.417]}\end{array}$ \\
\hline LnGDPPC & - & - & - & $\begin{array}{c}.467 * * * \\
{[.104]}\end{array}$ & $\begin{array}{c}.486 * * * \\
{[.111]}\end{array}$ \\
\hline $\mathrm{R}^{2}$ & .866 & .870 & .868 & .849 & .839 \\
\hline Valid N & 319 & 317 & 317 & 237 & 237 \\
\hline $\begin{array}{l}\text { Std. Errors in } \\
\text { brackets }\end{array}$ & & \multicolumn{4}{|c|}{$\begin{array}{c}* \text { sig. at } 10 \% ; * * \text { sig. at } 5 \% \\
* * * \text { sig. at } 1 \%\end{array}$} \\
\hline
\end{tabular}

Source: The authors (based on data analysis for the sample). 
Model IV follows a similar structure to model II, with the inclusion of GDP per capita and Gini index as additional controls. Its outcomes are somewhat similar to those found in model II, but stronger negative trends for FDI at very low levels of R\&D investment can be identified for every NIS dimension (except for HITECHX). ${ }^{9}$ For the case of Trademarks and Patents, this vector becomes significant (and negative). It is of little concern that results for model IV have weaker predictive powers than those found for the estimations of model II, since the inclusion of Gini caused a larger amount of missing observations.

Table 6

Estimations for LnHITECHX (dependent)

\begin{tabular}{|c|c|c|c|c|c|}
\hline Variables & Model I & Model II & Model III & Model IV & Model V \\
\hline const. & $\begin{array}{c}2.194 \\
{[4.974]}\end{array}$ & $\begin{array}{c}-2.387 \\
{[5.037]}\end{array}$ & $\begin{array}{c}-2.153 \\
{[4.950]}\end{array}$ & $\begin{array}{c}12.106^{* *} \\
{[5.793]}\end{array}$ & $\begin{array}{l}11.347^{*} \\
{[5.808]}\end{array}$ \\
\hline $\operatorname{LnK}$ & $\begin{array}{l}-.113 \\
{[.094]}\end{array}$ & $\begin{array}{l}-.108 \\
{[.090]}\end{array}$ & $\begin{array}{l}-.117 \\
{[.090]}\end{array}$ & $\begin{array}{c}-.222^{* *} \\
{[.095]}\end{array}$ & $\begin{array}{c}-.219^{* *} \\
{[.094]}\end{array}$ \\
\hline $\operatorname{LnL}$ & $\begin{array}{l}-.330 \\
{[.312]}\end{array}$ & $\begin{array}{l}-.061 \\
{[.306]}\end{array}$ & $\begin{array}{l}-.061 \\
{[.308]}\end{array}$ & $\begin{array}{c}-.966^{* * *} \\
{[.355]}\end{array}$ & $\begin{array}{c}-.878^{* *} \\
{[.358]}\end{array}$ \\
\hline LnFDI & $\begin{array}{l}.109^{*} \\
{[.062]}\end{array}$ & $\begin{array}{l}.147 \\
{[.095]}\end{array}$ & $\begin{array}{c}.038 \\
{[.077]}\end{array}$ & $\begin{array}{c}.166 \\
{[.111]}\end{array}$ & $\begin{array}{l}-.077 \\
{[.091]}\end{array}$ \\
\hline LnOPEN & $\begin{array}{l}.909^{* * *} \\
{[.201]}\end{array}$ & $\begin{array}{l}.847^{* * *} \\
{[.214]}\end{array}$ & $\begin{array}{c}.787^{* * *} \\
{[.200]}\end{array}$ & $\begin{array}{c}1.132^{* * *} \\
{[.228]}\end{array}$ & $\begin{array}{c}1.027^{* * *} \\
{[.210]}\end{array}$ \\
\hline LnINFLATION & $\begin{array}{c}-.121^{* * *} \\
{[.027]}\end{array}$ & $\begin{array}{c}-.113^{* * *} \\
{[.028]}\end{array}$ & $\begin{array}{c}-.112^{* * *} \\
{[.028]}\end{array}$ & $\begin{array}{c}-.130^{* * *} \\
{[.029]}\end{array}$ & $\begin{array}{c}-.135^{* * *} \\
{[.030]}\end{array}$ \\
\hline LnFDI*ABC1 & - & $\begin{array}{l}-.059 \\
{[.088]}\end{array}$ & - & $\begin{array}{l}-.138 \\
{[.101]}\end{array}$ & - \\
\hline LnFDI*ABC2 & - & - & $\begin{array}{c}.093 \\
{[.075]}\end{array}$ & - & $\begin{array}{l}.163^{*} \\
{[.088]}\end{array}$ \\
\hline $\mathrm{ABC} 2$ & - & - & $\begin{array}{l}.598 \\
{[.507]}\end{array}$ & - & $\begin{array}{l}1.017 \\
{[.617]}\end{array}$ \\
\hline LnGINI & - & - & - & $\begin{array}{l}.142 \\
{[.319]}\end{array}$ & $\begin{array}{c}.040 \\
{[.323]}\end{array}$ \\
\hline LnGDPPC & - & - & - & $\begin{array}{c}.027 \\
{[.081]}\end{array}$ & $\begin{array}{c}.001 \\
{[.083]}\end{array}$ \\
\hline $\mathrm{R}^{2}$ & .891 & .902 & .903 & .880 & .881 \\
\hline Valid N & 374 & 355 & 355 & 259 & 259 \\
\hline $\begin{array}{l}\text { Std. Errors in } \\
\text { brackets }\end{array}$ & \multicolumn{5}{|c|}{$\begin{array}{l}{ }^{*} \text { sig. at } 10 \% ;{ }^{* *} \text { sig. at } \\
5 \% \text {; }{ }^{* * *} \text { sig. at } 1 \%\end{array}$} \\
\hline
\end{tabular}

Source: The authors (based on data analysis for the sample).

9 It should be noticed that GDP per capita has a close conceptual relationship with productivity levels. Nonetheless, the correlation coefficient (.713) between these two variables reduces concerns of strong collinearity. Furthermore, the inclusion of GDPPC in robustness tests does not significantly alter the behavior of our variables of interest, reducing potential issues in models' specifications. 
So far, the inclusion of $\mathrm{ABC} 1$ in the analysis sustains the rationale of our research hypotheses, where innovation systems' evolution can benefit from the presence of foreign investment only at higher levels of R\&D efforts. This partial conclusion is relevant to assess results for models III and V, which focus on $\mathrm{ABC} 2$, a threshold variable based on the sample median for $\mathrm{ABC} 1$ (i.e., above $0.43 \%$ of GDP). Once more we would like to stress that this choice is arbitrary and further classifications according to different percentiles of the sample could be used. Nonetheless, the use of the median for such an evaluation is an intuitive and effective way to provide exploratory robustness tests for the group of countries under scrutiny. We will leave the application of distinct thresholds as a suggestion for future research in this topic.

Table 7

Estimations for LnTRDMRK (dependent)

\begin{tabular}{|c|c|c|c|c|c|}
\hline Variables & Model I & Model II & Model III & Model IV & Model V \\
\hline const. & $\begin{array}{c}1.603 \\
{[3.287]}\end{array}$ & $\begin{array}{c}1.749 \\
{[2.496]}\end{array}$ & $\begin{array}{c}-.310 \\
{[2.491]}\end{array}$ & $\begin{array}{l}5.184^{*} \\
{[3.022]}\end{array}$ & $\begin{array}{c}3.841 \\
{[3.112]}\end{array}$ \\
\hline LnK & $\begin{array}{l}.023 \\
{[.066]}\end{array}$ & $\begin{array}{l}.006 \\
{[.047]}\end{array}$ & $\begin{array}{c}-.012 \\
{[.047]}\end{array}$ & $\begin{array}{l}-.124 * * \\
{[.052]}\end{array}$ & $\begin{array}{c}-.137 * * * \\
{[.052]}\end{array}$ \\
\hline LnL & $\begin{array}{l}.508^{* *} \\
{[.205]}\end{array}$ & $\begin{array}{l}.564 * * * \\
{[.151]}\end{array}$ & $\begin{array}{l}.614^{* * *} \\
{[.154]}\end{array}$ & $\begin{array}{l}.209 \\
{[.184]}\end{array}$ & $\begin{array}{l}.226 \\
{[.191]}\end{array}$ \\
\hline LnFDI & $\begin{array}{l}.088 * * \\
{[.035]}\end{array}$ & $\begin{array}{l}-.068 \\
{[.049]}\end{array}$ & $\begin{array}{c}.018 \\
{[.040]}\end{array}$ & $\begin{array}{l}-.118 * * \\
{[.059]}\end{array}$ & $\begin{array}{c}.001 \\
{[.050]}\end{array}$ \\
\hline LnOPEN & $\begin{array}{l}.690^{* * *} \\
{[.134]}\end{array}$ & $\begin{array}{l}.405^{* * *} \\
{[.106]}\end{array}$ & $\begin{array}{l}.548 * * * \\
{[.100]}\end{array}$ & $\begin{array}{l}.487 * * * \\
{[.117]}\end{array}$ & $\begin{array}{c}.630^{* * *} \\
{[.114]}\end{array}$ \\
\hline LnINFLATION & $\begin{array}{c}-.066^{* * * *} \\
{[.019]}\end{array}$ & $\begin{array}{c}-.043 * * * \\
{[.015]}\end{array}$ & $\begin{array}{c}-.054 * * * \\
{[.015]}\end{array}$ & $\begin{array}{c}-.045^{* * *} \\
{[.017]}\end{array}$ & $\begin{array}{c}-.054^{* * *} \\
{[.017]}\end{array}$ \\
\hline LnFDI*ABC1 & - & $\begin{array}{l}.182 * * * \\
{[.046]}\end{array}$ & - & $\begin{array}{l}.173 * * * \\
{[.055]}\end{array}$ & - \\
\hline LnFDI*ABC2 & - & - & $\begin{array}{l}.102 * * * \\
{[.037]}\end{array}$ & - & $\begin{array}{c}.051 \\
{[.046]}\end{array}$ \\
\hline $\mathrm{ABC} 2$ & - & - & $\begin{array}{l}.840 * * * \\
{[.253]}\end{array}$ & - & $\begin{array}{c}.421 \\
{[.323]}\end{array}$ \\
\hline LnGINI & - & - & - & $\begin{array}{l}.255 \\
{[.173]}\end{array}$ & $\begin{array}{c}.213 \\
{[.177]}\end{array}$ \\
\hline LnGDPPC & - & - & - & $\begin{array}{l}.305 * * * \\
{[.044]}\end{array}$ & $\begin{array}{c}.301 \\
{[.046]}\end{array}$ \\
\hline $\mathrm{R}^{2}$ & .928 & .957 & .957 & .954 & .952 \\
\hline Valid N & 375 & 355 & 355 & 263 & 263 \\
\hline $\begin{array}{l}\text { Std. Errors in } \\
\text { brackets }\end{array}$ & & & \multicolumn{3}{|c|}{$\begin{array}{l}* \text { sig. at } 10 \% ; * * \text { sig. at } 5 \% ; \\
* * * \text { sig. at } 1 \%\end{array}$} \\
\hline
\end{tabular}

Source: The authors (based on data analysis for the sample). 
For model III, the validity of our research hypothesis only holds for the evaluation of labor productivity and registration of trademarks. In the case of labor productivity, once again a negative impact of "pure" FDI is offset by the presence of a stronger impact of the conditional interactive term (FDI*ABC2). Interestingly, the net effect is very close to that observed for model II, providing some confirmation for this particular assessment. In the case of trademarks, net effects diminish in a direct comparison with model II. Any sign of positive effects that were found in the estimations with $\mathrm{ABC} 1$ vanish from the approaches related to TFP growth and USPTO patenting activity. Hence, in this regard, we lose some confidence concerning the robustness of conclusions in terms of these two dimensions of NISs. Incidentally, it becomes risky to pinpoint the existence of clear and strong effects of FDI that spread across functioning and output constructs of innovation systems in developing nations.

This loss of significance in FDI and FDI*ABC2 for most assessments of model III for developing countries' innovation systems (in a comparison to models II and IV) can be explained by: (i) only mediating effects of R\&D efforts at rates largely above the median can actually facilitate the generation of FDI contributions to host economies; or (ii) FDI-related effects upon innovation systems are not strong enough to the point of presenting robust effects according to alternative model specifications for the assessment of conditional impacts upon developing countries' innovation systems (which is much in line with the propositions of Wooster and Diebel, 2010). In any case, either of these possible explanations recommends caution concerning expectations towards the relationship between these investments and host economies. Widespread perceptions that FDI plays a central role within innovation systems (GUIMÓN, 2009), should, we believe, be questioned and evaluated more thoroughly in face of empirical evidence.

The abovementioned arguments gain more strength in the evaluation of model V's outcomes. In this case, only labor productivity remains with a behavior that offers evidence in favor of the research hypothesis. Net effects of FDI also remain relatively stable across estimations, from which we derive a robust conclusion of the concentrated benefits arising from FDI within the realm of aggregate labor productivity in recipient economies. Registration of Trademarks, although presenting statistically significant information in model III, does not offer a validation of outcomes concerning ABC2 once we introduce GDP per capita and Gini index (model V).

In an integrated view of the role played by FDI in developing countries' NISs according to the set of indicators approached in this research, some preliminary 
remarks are in place. First, we find no support for unconditional benefits arising from FDI once mediating variables are incorporated in models. Furthermore, fully robust results in terms of statistical significance and level of positive net effects are concentrated in the evolution of labor productivity. There are hints of contributions associated with TFP growth, international patenting activity and registration of trademarks, but these seem to require environments with rather high levels of R\&D efforts (significantly above the median). However, this proposition is only speculative and deserves further attention in future investigations.

"Pure" or conditional effects of FDI upon export intensity in high-technology products could not be identified in our sample (possibly a function of MNCs internationalization strategies, as previously discussed). As we will discuss in the upcoming section, our empirical evidence does not warrant the existence of widespread benefits from FDI to innovation systems, at least in the case of developing countries. When these take place, however, they are strongly related to existing levels of absorptive capacity. Consequently, our research hypothesis can be accepted only to a limited extent.

\section{Concluding remarks}

This article has addressed the topic of FDI-related spillovers and aggregate contributions to developing countries' innovation systems. More specifically, we have addressed the mediating effects represented by a systemic proxy of absorptive capacities and stage of progress of NISs, i.e., R\&D efforts. More importantly, we have offered a novel assessment through the inclusion of five constructs that represent the functioning and output conditions of innovation systems: labor productivity, TFP growth, USPTO patents, export intensity in high-technology products, and registration of trademarks. To our best knowledge, this broader look upon the effects of FDI in host economies is unparalleled by previous studies in the field.

Overall results suggest a partial acceptance of the research hypothesis. We have confirmed that the inclusion of R\&D efforts as a mediator of FDI contributions to host innovation systems represents an important feature of the specification in econometric models. This procedure consistently sustains that such externalities are by no means "friction-free", as highlighted by the behavior of "pure" FDI (impacts of FDI at very low levels of R\&D expenditures) once interaction terms were incorporated in the analysis. In this regard, we have shown that in the absence of the proper conditions for appropriation of knowledge from MNCs, effects are either 
insignificant or detrimental to the evolution of developing countries' innovation systems.

Accordingly, two main conclusions can be drawn from the empirical exercise: benefits arising from FDI in emerging economies seem to be (i) contingent upon existing levels of aggregate absorptive capacity; and (ii) concentrated in specific dimensions of DC's innovation systems. The first remark provides support for our hypothesis stating that "the existence of FDI's positive impacts on the functioning and outcomes of developing countries' innovation systems is contingent upon existing aggregate levels of absorptive capacity as approximated by $R \& D$ expenditures". Nonetheless, estimations are only fully robust for models related to labor productivity, although with rather small net effects from FDI once we account for R\&D expenditures as a mediating construct. While there are reasons to expect some level of positive conditional impacts from FDI in TFP growth patterns, international patenting activity and registration of trademarks, results related to these models are not consistent enough to unequivocally warrant the endorsement of $\mathrm{H}_{1}$. For the case of export intensity in high-technology products, evidence does not ratify that FDI is related to positive outcomes.

From a systemic point of view, these empirical findings recommend caution in the evaluation of overall impacts of FDI in developing countries. Our assessment provides interesting new information to question the validity of propositions related to FDI's capacity of amplifying local aggregate innovative capabilities (BALASUBRAMANYAM et al., 1999), playing a central role within host markets' innovation systems (GUIMÓN, 2009), and representing "hubs" of skills, technology and managerial expertise (NOORBAKHSH; PALONI, 2001). At least in the context of developing countries, our sample shows that these assertions are overly optimistic and may establish inconsistent expectations for the relationship between FDI attraction and innovation policy. In other words, even within our limited assessment of complex innovation systems, results arising from the presence of FDI seem to be rather concentrated in a specific set of indicators, notoriously on labor productivity. From a long-term, evolutionary, viewpoint, however, productivity gains may positively affect the behavior of other constructs related to innovation systems' functioning and output. Of course this is only a tentative remark and this issue by itself represents an interesting avenue for further research.

Regarding implications of these findings, eventual benefits arising from FDI presence in developing markets seem to be related to aggregate-level absorptive capacities. If policies concerning the attraction of MNCs are related to evolutionary 
goals of innovation systems, then coordination amongst these dimensions is needed. This is so because of sectoral and regional heterogeneities within developing nations (an issue that deserves further attention from empirical perspectives) in terms of NIS's capabilities. ${ }^{10}$ Hence, subsidies and other forms of incentives for FDI allocation should be preceded by environments conducive to the generation of productivity gains.

By the same token, evaluation, screening and selection of FDI initiatives would then be able to promote FDI inflows in those industries and regions that have already achieved sufficient levels of innovative and absorptive capabilities (KOKKO, 1994; LALL, 1992; GUIMÓN, 2009), connecting FDI with specific development objectives (as suggested by Fu, 2012). Incidentally, not all FDI can be regarded as beneficial for developing countries' innovation systems, making the case for a critical understanding of multinational corporations as agents of knowledge dissemination.

We recognize, however, that these suggestions should be considered cautiously, as these matters still deserve further attention. While the methodological structure of our research has provided relevant information on the relationship between innovative efforts and the dynamics of FDI in developing nations, we must be aware that econometric models are of a limited reach within the complexity of NISs. Additional statistical tests using a Schumpeterian rationale represent a promising avenue for future research. ${ }^{11}$ Yet, there is little reason to believe that FDI per se performs the expected levels of knowledge diffusion. Its inclusion and interaction with broader concepts of innovation policy is an essential part of an institutional environment that facilitates the generation of benefits related to the attraction of productive investments. Even in the presence of the proper conditions, there are limits to the contributions of these investments and its inclusion in the innovation policy debate should be managed without unwarranted enthusiasm.

\section{References}

AITKEN, B.; HARRISON, A. Do domestic firms benefit from direct foreign investment? Evidence from Venezuela. American Economic Review, v. 89, n. 3, p. 605-618, 1999.

ALFARO, L.; CHANDA, A.; KALEMLI-OZCAN, S.; SAYEK, S. FDI and economic growth: the role of local financial markets. Journal of International Economics, v. 64, n. 1, p. 89-112, 2004.

10 For a discussion of the Brazilian case, see Fischer and Tello-Gamarra (2014).

11 For instance, applying an adaptation of the model found in Fagerberg et al. (2007). We would like to thank an anonymous reviewer for pointing this out. 
ALONSO, J.; GARCIMARTÍN, C. Criterios y factores de calidad institucional: un estudio empírico. Revista de Economía Aplicada, v. 19, n. 55, p. 5-32, 2011.

BALASUBRAMANYAM, V.; SALISU, M.; SAPSFORD, D. Foreign direct investment and growth in EP and IS countries. The Economic Journal, v. 106, n. 434, p. 92-105, 1996.

BALASUBRAMANYAM, V.; SALISU, M.; SAPSFORD, D. Foreign direct investment as an engine of growth. The Journal of International Trade \& Economic Development, v. 8, n. 1, p. $27-40,1999$.

BLALOCK; G.; SIMON, D. Do all firms benefit equally from downstream FDI? The moderating effect of local suppliers' capabilities on productivity gains. Journal of International Business Studies, v. 40, n. 7, p. 1095-1112, 2009.

BLOMSTROM, M.; LIPSEY, R.; ZEJAN, M. Is fixed investment the key to economic growth? The Quarterly Journal of Economics, v. 111, n. 1, p. 269-276, 1996.

BLOMSTROM, M.; PERSSON, H. Foreign direct investment and spillover efficiency in an underdeveloped economy: evidence from the Mexican manufacturing industry. World Development, v. 11, n. 6, p. 493-501, 1983.

BORENSZTEIN, E.; DE GREGORIO, J.; LEE, J. How does foreign direct investment affect economic growth? Journal of International Economics, v. 45, n. 1, p. 115-135, 1998.

CARKOVIC, M.; LEVINE, R. Does foreign direct investment accelerate economic growth? Minneapolis MN: University of Minnesota Department of Finance, 2002 (Working paper).

CASTELLACI, F.; NATERA, J. A new panel dataset for cross-country analyses of national systems, growth and development (CANA). Innovation and Development, v. 1, n. 2, p. 205-226, 2011.

The dynamics of national innovation systems: a panel cointegration analysis of the coevolution between innovative capability and absorptive capacity. Research Policy, v. 42, n. 3, p. 579-594, 2013.

COE, D.; HELPMAN, E. International R\&D spillovers. European Economic Review, v. 39, n. 5, p. 859-887, 1995.

COHEN, W.; LEVINTHAL, D. Absorptive capacity: a new perspective on learning and innovation. Administrative Science Quarterly, v. 35, n. 1, p. 128-152, 1990.

DE MELLO, L. Foreign direct investment in developing countries and growth: a selective survey. Journal of Development Studies, v. 34, n. 1, p. 1-34, 1997. 
DUNNING, J. Multinational enterprises and the globalization of innovatory capacity. Research Policy, v. 23, n. 1, p. 67-88, 1994.

FAGERBERG, J.; SRHOLEC, M.; KNELL, M. The competitiveness of nations: why some countries prosper while others fall behind. World Development, v. 35, n. 10, p. 1595-1620, 2007.

FISCHER, B.; TELLO-GAMARRA, J. Capacidades absortivas setoriais e a evolução do Brasil no Investment Development Path. Revista Gestão \& Conexôes, v. 3, n. 2, p. 134-155, 2014.

FRANSMAN, M. Is national technology policy obsolete in a globalized world? The Japanese response. Cambridge Journal of Economics, v. 19, n. 1, p. 95-119, 1995.

FU, X. Foreign direct investment, absorptive capacity and regional innovation capabilities: evidence from China. Oxford Development Studies, v. 36, n. 1, p. 89-110, 2008.

FURTADO, A.; CARVALHO, R. Padrōes de intensidade tecnológica da indústria brasileira: um estudo comparativo com os países centrais. São Paulo em Perspectiva, v. 19, n. 1, p. 70-84, 2005.

GIRMA, S. Absorptive capacity and productivity spillovers from FDI: a threshold regression analysis. Oxford Bulletin of Economics and Statistics, v. 67, n. 3, p. 281-306, 2005.

GUIMÓN, J. Government strategies to attract R\&D intensive FDI. The Journal of Technology Transfer, v. 34, n. 4, p. 364-379, 2009.

KINOSHITA, Y. R\&D and technology spillovers via FDI: innovation and absorptive capacity. Ann Arbor, MI: William Davidson Institute at the University of Michigan, 2000 (Working paper, n. 349).

KOKKO, A. Technology, market characteristics, and spillovers. Journal of Development Economics, v. 43, n. 2, p. 279-293, 1994.

LALL, S. Technological capabilities and industrialization. World Development, v. 20, n. 2, p. 165-186, 1992.

MANKIW, N.; ROMER, D.; WEIL, D. A contribution to the empirics of economic growth. The Quarterly Journal of Economics, v. 107, n. 2, p. 407-437, 1992.

MAYER-FOULKES, D.; NUNNENKAMP, P. Do multinational enterprises contribute to convergence or divergence? A disaggregated analysis of US FDI. Review of Development Economics, v. 13, n. 2, p. 304-318, 2009.

NAIR-REICHERT, U.; WEINHOLD, D. Causality tests for cross-country panels: a new look at FDI and economic growth in developing countries. Oxford Bulletin of Economics and Statistics, v. 63, n. 2, p. 153-171, 2001. 
NARULA, R. The importance of domestic capabilities for FDI-assisted development: lessons from Asia and Latin America. Reading: Henley Business School, University of Reading, 2015 (Discussion paper n. JHD-2015-05).

NARULA, R.; DUNNING, J. Multinational enterprises, development and globalization: some clarifications and a research agenda. Oxford Development Studies, v. 38, n. 3, p. 263 $287,2010$.

NOORBAKHSH, F; PALONI, A. Human capital and FDI inflows to developing countries: new empirical evidence. World Development, v. 29, n. 9, p. 1593-1610, 2001.

PEREZ, T. Multinational enterprises and technological spillovers: an evolutionary model. Journal of Evolutionary Economics, v. 7, n. 2, p. 169-192, 1997.

POTTELSBERGHE, B.; LICHTENBERG, F. Does foreign direct investment transfer technology across borders? Review of Economics and Statistics, v. 83, n. 3, p. 490-497, 2001. WARWICK, K. Beyond industrial policy: emerging issues and new trends. Paris: OECD, 2013 (Science, Technology and Industry Policy Papers n. 2).

WOOLDRIDGE, J. Econometric analysis of cross section and panel data. 2nd. ed. Cambridge: The MIT Press, 2000.

WOOSTER, R.; DIEBEL, D. Productivity spillovers from foreign direct investment in developing countries: a meta-regression analysis. Review of Development Economics, v. 14, n. 3, p. 640-655, 2010.

$\mathrm{XU}, \mathrm{B}$. Multinational enterprises, technology diffusion, and host country productivity growth. Journal of Development Economics, v. 62, n. 2, p. 477-493, 2000.

ZUCOLOTO, G.; TONETO JR., R. Esforço tecnológico da indústria de transformação brasileira: uma comparação com países selecionados. Revista de Economia Contemporânea, v. 9, n. 2, p. 337-365, 2005. 


\section{Appendix I - Countries included in the empirical approach}

\section{Developing countries (upper-middle income)}

Albania, Algeria, Argentina, Botswana, Brazil, Bulgaria, Chile, China, Colombia, Costa Rica, Ecuador, Iran, Jamaica, Jordan, Kazakhstan, Latvia, Lebanon, Lithuania, Malaysia, Mexico, Namibia, Panama, Peru, Romania, Russia, South Africa, Thailand, Tunisia, Turkey, Uruguay, Venezuela. 